Reprinted with permission from: Weed Science. 1986. 34(6):911-915.

Published and copyrighted by: Weed Science Society of America. http://www.wssa.net

\title{
Identification and distribution of the weedy spurges in the Delta of Mississippi ${ }^{1}$
}

\author{
C. DENNIS ELMORE and SIDNEY McDANIEL
}

Plant Physiol., USDA/ARS, Stoneville, MS 38776 and Prof. of Bot., Dep. Biol. Sci., Mississippi State Univ., Mississippi State, MS 39762, respectively.

\begin{abstract}
:
The weedy spurges found in the Delta region of Mississippi, U.S.A., include spotted spurge (Euphorbia maculata L. \#² EPHMA), nodding spurge (Euphorbia nutans Lag. \# EPHNU), prostrate spurge (Euphorbia humistrata Engelm. ex Gray \# EPHHT), creeping spurge (Euphorbia serpens H.B.K. \# EPHSN), and hyssop spurge (Euphorbia hyssopifolia L. \#EPHHS). Nodding spurge was the most common while creeping spurge was the least common. Hyssop spurge, not previously known to be in Mississippi, was found in six of the 17 counties in the Delta of Mississippi. Hyssop spurge occurs with, and had previously been confused with, nodding spurge. Diagnostic characters, special identification features, and illustrations are provided to aid in identification of these five species of weedy spurges, which occur widely in the U.S.
\end{abstract}

\section{Additional Index words:}

Taxonomy, Euphorbia supina, Euphorbia maculata, Euphorbia humistrata, Euphorbia nutans, Euphorbia serpens, Euphorbia hyssopifolia, EPHMA, EPHHT, EPHNU, EPHSN, EPHHS.

\section{Introduction}

\footnotetext{
${ }^{1}$ Received for publication January 31, 1986, and in revised form June 21, 1986. The authors are Plant Physiol., USDA/ARS, Stoneville, MS 38776 and Prof. of Bot., Dep. Biol. Sci., Mississippi State Univ., Mississippi State, MS 39762.

${ }^{2}$ Letters following this \# symbol are a WSSA-approved computer code from Composite List of Weeds, Weed Sci. 32 , Suppl. 2. Available from WSSA, 309 West Clark Street, Champaign, IL 61820.
} 
The spurges have recently emerged as important troublesome weeds, especially in cotton, in the mid-South of the U.S.A. (6). Their distribution was reported in some detail in 1979 by Dunn (4), but he noted that there was considerable taxonomic confusion surrounding the species spotted spurge (E. maculata) and prostrate spurge (E. supina). Because these are important weeds and since the new composite list of weeds (12) has adopted a different nomenclature for these weedy spurges, distribution and frequency are reported on a county basis in the Delta area of Mississippi. We are also reporting the reasons for the taxonomic confusion and providing a rationalization for the names as adopted by the Weed Science Society of America. This report is similar to those reported by others for additional classes of taxonomically difficult weed species $(1,11)$, except for the limited distribution that we are reporting. However, the taxonomy and name clarification applies generally.

\section{Materials and methods}

In the summer of 1983, a survey was taken in 17 counties of the Delta of Mississippi, the flood plain of the Mississippi River located in Mississippi, U.S.A. This area is bounded by loessial deposits on the east which form a distinct boundary and by the Mississippi River on the west. The loessial deposits join the river to the north and south to make a clearly separable area with no equivocation. The survey consisted of locating a site in a county, which was clearly an agricultural site (i.e., a planted field or an intentionally fallowed field) and listing all of the spurge species found. A total of 54 sites were visited. Material for photography was collected in the field in the vicinity of Stoneville, MS, or from herbarium specimens. Annotated voucher specimens are in the herbaria at Stoneville and Mississippi State, MS.

In September of 1985 a second survey was undertaken to document the occurrence of hyssop spurge and nodding spurge in cotton and soybean fields. Routes were selected that traversed all of the counties in the region. The first cotton or soybean field encountered after traveling $16 \mathrm{~km}$ was sampled. The presence and abundance of hyssop spurge and nodding spurge were recorded. The abundance rating used was that described previously (5). It consists of a rating scale from 0 (none present) to 5 (over $50 \%$ ground area covered).

\section{Results and discussion}

Spurge distribution in the Delta of Mississippi. Nodding spurge was the most frequently encountered spurge. It was found in 16 of the 17 counties visited and on $83 \%$ of the sites (Table 1). The prostrate spurges were not found as frequently individually or collectively. There were 15 sites where nodding spurge was found which had neither spotted nor prostrate spurge. Even without differentiating between spotted spurge and prostrate spurge, nodding spurge was thus more widely distributed in the Delta of Mississippi.

Page 2 of 8 
Prostrate spurge and spotted spurge were found with equal frequency and some expertise was required to tell them apart. Spots on the leaves are not a basis for differentiation, but the node rooting characteristic of prostrate spurge is sufficiently consistent to be useful. This feature allows prostrate spurge to develop larger plants, which frequently occupied up to $0.5 \mathrm{~m}$ sq. Both species are found in the same habitats and while appearing 'weedy' are not considered sufficiently competitive to be listed in worst weed lists of the Southern U.S. (6). One other spurge with prostrate growth habit, creeping spurge, was found only in one county at two sites, although it was locally abundant at one site.

Table 1. Number of counties and sites within counties in the Delta of Mississippi in which weedy spurges occurred.

\begin{tabular}{lccc}
\hline Species & \multicolumn{2}{c}{ Counties } & \multicolumn{2}{c}{ Sites } \\
\hline & 16 & (no.) & $(\%)$ \\
Nodding spurge $^{\mathrm{a}}$ & 15 & 45 & 83 \\
Spotted spurge & 14 & 28 & 52 \\
Prostrate spurge & 1 & 21 & 44 \\
Creeping spurge & 17 & 2 & 4 \\
Total & 54 & $\ldots$ \\
${ }^{\mathrm{a}}$ This survey did not discriminate between nodding and hyssop spurge.
\end{tabular}

${ }^{\mathrm{a}}$ This survey did not discriminate between nodding and hyssop spurge.

Subsequent to the first survey it was determined that a second species of spurge with erect growth habit was present in the area (hyssop spurge). Thus the first survey could have included both nodding spurge and hyssop spurge and referred to it as nodding spurge. The second survey was conducted solely to determine the distribution and abundance of these two species in cotton and soybean fields in the Delta of Mississippi. A total of 97 cotton and soybean fields were sampled in 17 counties (Table 2). Only nine of the sampled fields had neither of the spurges present. Nodding spurge was found in each county sampled except one (DeSoto), but hyssop spurge was found in only six counties. Hyssop spurge was found more often, and with greater abundance, in cotton fields than in soybean fields. Nodding spurge is approximately three times as abundant in this region as hyssop spurge. Hyssop spurge has a more localized distribution, while nodding spurge is more generally distributed, with equal abundance ratings in cotton and soybean fields. A tendency was noted for hyssop spurge to be found in sites with coarse-textured soils, while nodding spurge may be found wherever crops are grown.

Elements of the controversy regarding $\boldsymbol{E}$. maculata. According to both Wheeler (17) and Burch (2), Linnaeus gave the trivial name Euphorbia maculata to species 21 in Species Plantarum. The complete entry consists of reference to earlier works, an indication of habitat and, in this case, a supplementary description including color. The problem is that there are two herbarium sheets bearing the name E. maculata (sheets 17 and 21). One is a prostrate, pubescent plant; the other an erect, glabrous one. Clearly the name applies to only one of them, but which species is the one intended to be E. maculata by 
Linnaeus is not clear. Apparently taxonomists before 1939 were content with the prostrate, pubescent plant as being the one Linnaeus intended to be E. maculata (16). Wheeler (16) in 1939 examined photographs and records and decided that Linneaus really intended the erect, glabrous plant to be E. maculata. He later visited the herbarium and confirmed his earlier position (17). Since he was a specialist in the Euphorbiaceae and of the subgenus Chamesyce in particular, he convinced many prominent taxonomists $(7,9,13$, $15)$.

Table 2. Distribution and abundance of hyssop and nodding spurge in cotton and soybean fields in the Delta of Mississippi.

\begin{tabular}{|c|c|c|c|c|c|c|c|c|}
\hline \multirow[b]{2}{*}{ County } & \multicolumn{2}{|c|}{ Crop site } & \multicolumn{3}{|c|}{ Hyssop spurge } & \multicolumn{3}{|c|}{ Nodding spurge } \\
\hline & Cotton & Soybean & Cotton & Soybean & Mean & Cotton & Soybean & Mean \\
\hline & 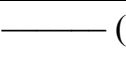 & -) & & 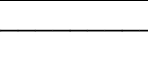 & - (abun & $\left.e^{a}\right)$ & & \\
\hline Bolivar & 3 & 10 & 0.0 & 0.3 & 0.2 & 1.0 & 1.2 & 1.2 \\
\hline Coahoma & 5 & 2 & 0.2 & 0.0 & 0.1 & 1.4 & 1.0 & 1.3 \\
\hline DeSoto $^{\mathrm{b}}$ & 2 & 0 & 4.0 & $\ldots$ & 4.0 & 0.0 & $\ldots$ & 0.0 \\
\hline Holmes & 1 & 1 & 0.0 & 0.0 & 0.0 & 1.0 & 1.0 & 1.0 \\
\hline Humphrets & 2 & 3 & 0.0 & 0.0 & 0.0 & 1.0 & 0.7 & 0.8 \\
\hline Issaquena & 0 & 1 & $\ldots$ & 0.0 & 0.0 & $\ldots$ & 1.0 & 1.0 \\
\hline Leflore & 5 & 3 & 0.2 & 0.0 & 0.1 & 1.6 & 1.3 & 1.5 \\
\hline Panola & 2 & 2 & 0.0 & 0.0 & 0.0 & 2.5 & 2.0 & 2.2 \\
\hline Quitman $^{\mathrm{b}}$ & 0 & 4 & $\ldots$ & 0.0 & 0.0 & $\ldots$ & 0.5 & 0.5 \\
\hline Sharkey & 3 & 3 & 1.7 & 0.7 & 1.2 & 0.7 & 1.7 & 1.2 \\
\hline Sunflower & 5 & 6 & 0.0 & 0.0 & 0.0 & 1.8 & 0.8 & 1.3 \\
\hline Tallahatchie & 3 & 2 & 0.0 & 0.0 & 0.0 & 2.0 & 0.5 & 1.4 \\
\hline Tate $^{\mathrm{b}}$ & 0 & 1 & $\ldots$ & 0.0 & 0.0 & $\ldots$ & 1.0 & 1.0 \\
\hline Tunica & 3 & 4 & 0.0 & 0.0 & 0.0 & 0.7 & 1.5 & 1.1 \\
\hline Warren ${ }^{\mathrm{b}}$ & 0 & 2 & $\ldots$ & 0.0 & 0.0 & $\ldots$ & 2.0 & 2.0 \\
\hline Washington & 9 & 4 & 2.0 & 0.2 & 1.5 & 1.0 & 1.5 & 1.2 \\
\hline Yazoo & 2 & 4 & 0.0 & 0.0 & 0.0 & 1.5 & 2.0 & 1.8 \\
\hline Total & 45 & 52 & & & & & & \\
\hline Means abundance & & & 0.7 & 0.1 & 0.4 & 1.2 & 1.2 & 1.2 \\
\hline
\end{tabular}

Burch (2) reexamined the records, including the actual herbarium specimens, and reached the opposite conclusion. His arguments seem reasonable and a number of publications and floras have since adopted his position $(3,8,14)$. The pubescent, prostrate species is thus E. maculata L., spotted spurge. Once E. maculata is defined, then the other species fall into place readily. E. nutans then is the erect plant with villous stems and glabrous capsules. E. hyssopifolia is also an erect plant, but with glabrous stems and 
capsules. E. humistrata (prostrate spurge) becomes the pubescent, prostrate spurge which roots at the nodes and E. serpens (creeping spurge) is the prostrate, glabrous species.

The name E. supina then becomes obsolete and is no longer to be used. Its former usage actually referred to two distinguishable species. Continued use of E. supina is not in accord with the present WSSA Composite List of Weeds (12). A concise species description for these spurge species is given in Table 3 . The information in the table is taken from the species descriptions of Correll and Johnston (3), Wheeler (17), Krochmal (10), and Godfrey and Wooten (8), as well as personal observations.

Table 3. Diagnostic characters of the Euphorbia species found in the Delta of Mississippi.

\begin{tabular}{|c|c|c|c|c|c|}
\hline \multirow[b]{2}{*}{ Character } & \multicolumn{5}{|c|}{ Species } \\
\hline & Nodding & Hyssop & Spotted & Prostrate & Creeping \\
\hline$\underline{\text { Habit }}$ & $\begin{array}{l}\text { Ascending to } \\
\text { erect }\end{array}$ & Ascending to erect & $\begin{array}{l}\text { Prostrate or } \\
\text { decumbent }\end{array}$ & $\begin{array}{c}\text { Prostrate } \\
\text { rooting }\end{array}$ & $\begin{array}{c}\text { Prostrate } \\
\text { rooting }\end{array}$ \\
\hline$\underline{\text { Stems }}$ & To 1 in & To $60 \mathrm{~cm}$ & $10-45 \mathrm{~cm}$ & $10-45 \mathrm{~cm}$ & $5-40 \mathrm{~cm}$ \\
\hline Pubescence & $\begin{array}{l}\text { Yes, on distal } \\
\text { internodes }\end{array}$ & No & Yes & Yes & No \\
\hline$\underline{\text { Leaf }}$ & $8-40 \mathrm{~mm}$ & $5-30 \mathrm{~mm}$ & 4-17 mm & $4-17 \mathrm{~mm}$ & $2-7 \mathrm{~mm}$ \\
\hline Margin & Serrate & Serrate & Serrulate & Serrulate & Entire \\
\hline Pubescence & $\begin{array}{l}\text { Glabrous or } \\
\text { pilose }\end{array}$ & $\begin{array}{l}\text { Occasionally } \\
\text { pilose }\end{array}$ & $\begin{array}{l}\text { Sparsely to densely } \\
\text { villous }\end{array}$ & Sparsely vilous & No \\
\hline Petioles & $1-2 \mathrm{~mm}$ & $1-1.5 \mathrm{~mm}$ & $0.6-1.5 \mathrm{~mm}$ & $1-1.5 \mathrm{~mm}$ & $0.5-1.0 \mathrm{~mm}$ \\
\hline Pubescence & No & No & Yes & Yes & No \\
\hline Cyanthia & $\begin{array}{l}\text { Solitary or in } \\
\text { cymes }\end{array}$ & Solitary & $\begin{array}{l}\text { Solitary, but } \\
\text { clustered by } \\
\text { shortened } \\
\text { internodes }\end{array}$ & $\begin{array}{l}\text { Solitary, but } \\
\text { clustered by } \\
\text { shortened } \\
\text { internodes }\end{array}$ & Solitary \\
\hline$\underline{\text { Glands }}$ & Circular & Circular & Oblong & Oblong & Oblong \\
\hline Appendages & $\begin{array}{l}\text { White or rarely } \\
\text { red }\end{array}$ & $\begin{array}{l}\text { White to red or } \\
\text { purple }\end{array}$ & White or pink & White & White \\
\hline$\underline{\text { Stamens }}$ & $\begin{array}{l}\text { 5-11 per } \\
\text { cyathium }\end{array}$ & 4-15 per cyathium & 2-5 per cyathium & $\begin{array}{l}2-5 \text { per } \\
\text { cyathium }\end{array}$ & $\begin{array}{l}\text { 3-8 per } \\
\text { cyathium }\end{array}$ \\
\hline$\underline{\text { Style }}$ & 3 & 3 & 3 & 3 & 3 \\
\hline Length & $0.6-1.0 \mathrm{~mm}$ & $0.5-0.9 \mathrm{~mm}$ & $0.3-0.4 \mathrm{~mm}$ & $0.5-0.7 \mathrm{~mm}$ & $0.2-0.5 \mathrm{~mm}$ \\
\hline Bifid & $1 / 2$ of length & $<1 / 2$ of length & $1 / 4-1 / 3$ of length & $1 / 2$ of length & Notched \\
\hline \multicolumn{6}{|l|}{ Capsule } \\
\hline Pubescence & Glabrous & Glabrous & Pubescent & Pubescent & Glabrous \\
\hline Size & $1.9-2.3 \mathrm{~mm}$ long & $1.5-2.1 \mathrm{~mm}$ long & $1.3-1.8 \mathrm{~mm}$ long & $\begin{array}{l}1.3-1.6 \mathrm{~mm} \\
\text { long }\end{array}$ & $\begin{array}{l}1-1.2 \mathrm{~mm} \\
\text { long }\end{array}$ \\
\hline \multicolumn{6}{|l|}{$\underline{\text { Seed }}$} \\
\hline Size & $1.1-1.6 \mathrm{~mm}$ & $1-1.4 \mathrm{~mm}$ & $0.8-1.1$ & $0.8-1.1 \mathrm{~mm}$ & $0.7-1.0 \mathrm{~mm}$ \\
\hline Color & Dark brown & Pale to dark brown & Pale brown & Pale brown & Pale brown \\
\hline Features & Wrinkled & Ridged & Ridged & Wrinkled & Smooth \\
\hline
\end{tabular}


Common features of all these species include opposite leaves with inequilateral bases, milky sap, and the flower structure unique to the subgenus Chamesyce. Key features to distinguish species are given in Table 4 . The leaf spot may or may not be present, even in spotted spurge, and thus should not be used as a diagnostic character.

Table 4. Special features that may be used to distinguish the weedy spurge species from each other.

\begin{tabular}{ll}
\hline Species & Features \\
\hline Nodding spurge - & $\begin{array}{l}\text { erect with glabrous capsules and pubescence on the distal internodes, seed dark } \\
\text { brown, wrinkled. }\end{array}$ \\
Hyssop spurge - & $\begin{array}{l}\text { erect with glabrous capsules but no pubescence on the distal internodes, seed pale } \\
\text { brown, ridged. }\end{array}$ \\
Spotted spurge - & $\begin{array}{l}\text { prostrate with pubescent stems and capsules, does not root at the nodes, styles } \\
\text { short, seed pale brown, ridged. }\end{array}$ \\
Prostrate spurge - & $\begin{array}{l}\text { prostrate with pubescent stems and capsules, does root at the nodes, styles long, } \\
\text { seed pale brown, wrinkled. }\end{array}$ \\
Creeping spurge - & prostrate with glabrous stems and capsules, style merely notched, seed smooth. \\
\hline
\end{tabular}

Nodding spurge and hyssop spurge are difficult to distinguish without a lens. But the characters, hairy or glabrous stems, and wrinkled or ridged seed, are discernible and consistent. These characters are shown in Figure 1.

Of the three species of prostrate spurge, one is easily distinguished by its glabrous stems and capsules and smooth seed (Figure 1). The other two species are more difficult because they both have pubescent stems and capsules. The node-rooting character of prostrate spurge is useful, as well as the longer style length and ridged seed (Figure 1).

Distribution $(3,10,16)$ could be useful for some of the spurges. Hyssop spurge is a tropical species with a distribution only in the Southern U.S. Nodding spurge is a northern plant overlapping with hyssop in some parts of Southern U.S. Creeping spurge is widespread throughout tropical and temperate America to Ontario. Prostrate spurge and spotted spurge also have coincident ranges in the eastern half of the U.S. Prostrate spurge may not be as prevalent in the West.

Among the frustrations of trying to key out a plant is not being able to find it in the reference book or flora. For these spurge species only two books have all species as we presented them: The Manual of the Vascular Plants of Texas (3), and Aquatic and Wetland Plants of the Southeastern U.S. (albeit as Chamesyce) (8).

Some of these characters used to differentiate species may seem trivial and may require more precision for identification than is seemingly warranted for normal studies of weeds. But these differences are genuine and have stood the test of generations of taxonomic probing. The task for weed scientists is to accept the proposed nomenclature, determine with sufficient precision the correct species identification and then, based upon research data, determine if there are differences in weed control which need to be considered. 

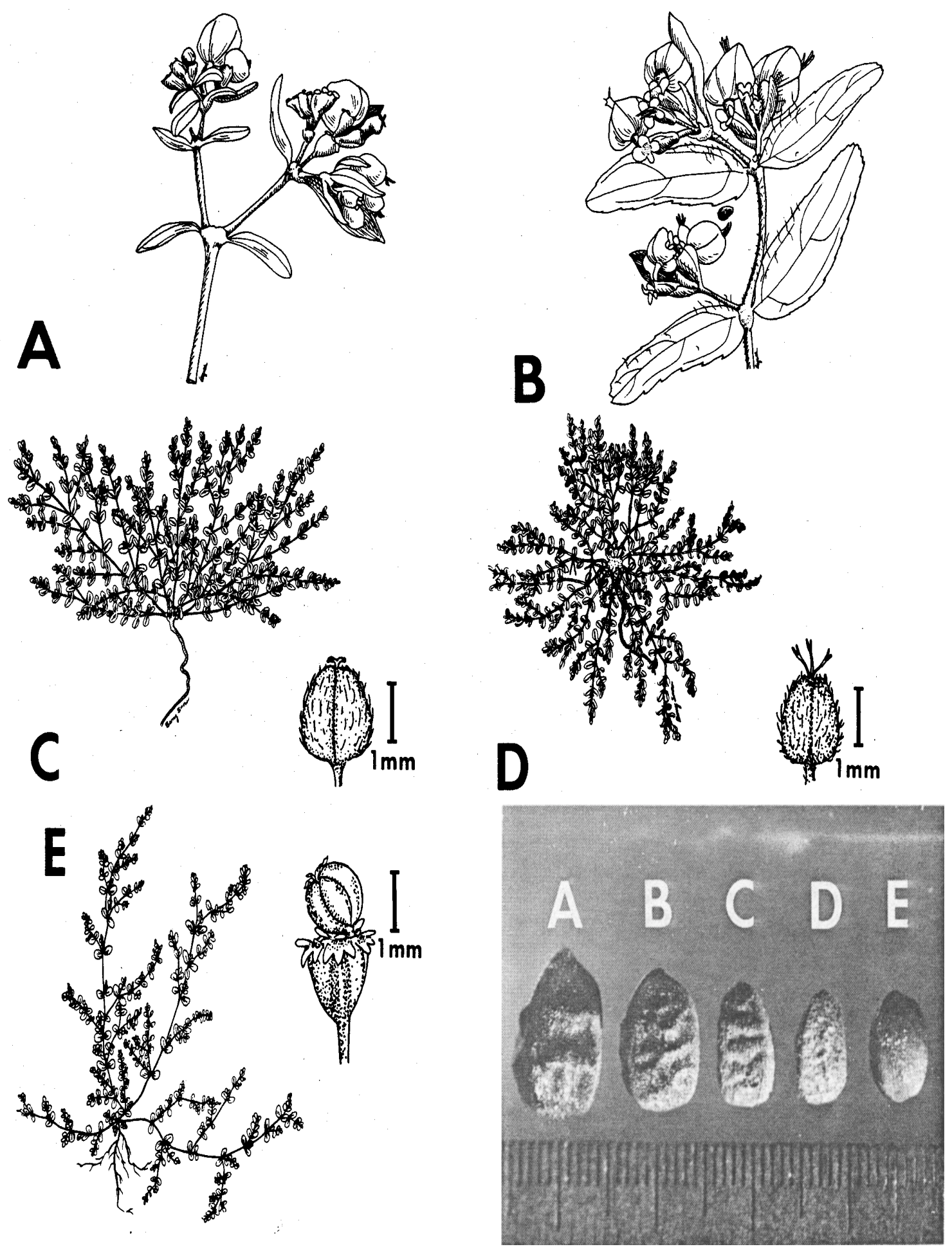

Figure 1. Line drawings and photomicrograph of 5 species of spurges: A) hyssop spurge, $B$ ) nodding spurge, $C$ ) spotted spurge, D) prostrate spurge, and E) creeping spurge. Plants in A) are times 2; B) are times 3, and C, D, E) are 1/4 actual size. The fruits in C, D, and E are enlarged to show detail with a $\mathrm{mm}$ scale bar. In the photomicrograph of the seed, one division equals $0.1 \mathrm{~mm}$. 


\section{Acknowledgments}

The authors thank Mr. Rex N. Paul, Jr., for advice, Mr. Lester Saucier for excellent technical assistance, and Dr. Michael Huft, Field Museum of Natural History, Chicago, IL, for annotating the herbarium sheets.

\section{Literature cited}

1. Ahrens, W. H., L. M. Wax, and E. W. Stoller. 1981. Identification of triazine-resistant Amaranthus spp. Weed Sci. 29:345-348.

2. Burch, D. 1966. The application of the Linnaeus names of some new world species of Euphorbia subgenus Chamesyce. Rhodora 68:155-166.

3. Correll, D. S, and M. C. Johnston. 1979. Manual of the Vascular Plants of Texas. Univ. of Texas at Dallas, Richardson, TX. 1881 pp.

4. Dunn, P. H. 1979. The distribution of leafy spurge (Euphorbia esula) and other weedy Euphorbia spp. in the United States. Weed Sci. 27:509-516.

5. Elmore, C. D. and S. McDaniel. 1983. Morningglories in the Delta of Mississippi. Bull. 920. MAFES Miss. State, MS. 11 pp.

6. Elmore, C.D. 1984. Weed Survey - Southern States. 1984 South. Weed Sci. Soc. Res. Rep. 37:192-198.

7. Fernald, M. L. 1950. Gray's Manual of Botany. 8th ed. American Book Co., New York. 1632 pp.

8. Godfrey, R. K. and J. W. Wooten. 1981. Aquatic and Wetland Plants of Southeastern United States: Dicotyledons, Univ. of GA Press, Athens, GA. 933 pp.

9. Gunn, C. R., T. M. Pullen, E. A. Stadelbacher, J. M. Chandler, and J. Barnes. 1980. Vascular Flora of Washington County Mississippi and Environs. Agric. Res. (South Reg.) Sci. and Ed. Admin., USDA, New Orleans, LA. 150 pp.

10. Krochmal, A. 1952. Seeds of weedy Euphorbia species and their identification. Weeds 1:243-255.

11. Ogg, A. G., Jr., B. S. Rogers, and E. E. Schilling. 1981. Characterization of black nightshade (Solanum nigrum) and related species in the United States. Weed Sci. 29:27-32.

12. Patterson, D. T. 1984. Composite List of Weeds. Weed Sci. 32 (Suppl. 2) 1-137.

13. Radford, A. E., H. E. Ahles, and C. R. Bell. 1964. Manual of the vascular flora of the Carolinas. Univ. of North Carolina Press. Chapel Hill. 1183 pp.

14. Richardson, J. W. 1968. The genus Euphorbia of the high plains of Kansas, Nebraska, South and North Dakota. Univ. Kans. Sci. Bull. 48:45-112.

15. Steyermark, J. A. 1963. Flora of Missouri. Iowa State Univ. Press, Ames, Iowa, 1728 pp.

16. Wheeler, L. C. 1939. A miscellany of New World Euphorbiaceae II. Contribution Gray Herb. 127:48-78.

17. Wheeler, L. C. 1960. Typification of Euphorbia maculata. Rhodora 62:134-141. 